\title{
Immunoregulatory $\mathrm{T}$ cells in the peripheral blood of patients with Bechterew's syndrome
}

\author{
ODD VINJE, JAN H. DOBLOUG, ØYSTEIN FøRRE, PÅL MøLLER, \\ AND OVE J. MELLBYE
}

From the Institute of Immunology and Rheumatology, the National Hospital; Oslo Sanitetsforenings Rheumatism Hospital; and Institute of Medical Genetics, University of Oslo, Oslo, Norway

SUMMARY Seventeen patients with ankylosing spondylitis (Bechterew's syndrome) were investigated. Only 3 of them had detectable autoantibodies, but the $\operatorname{IgA}$ and IgM concentrations in serum were increased $(\mathrm{p}<0.05)$. The patients had a moderate reduction in con-A-induced suppressor cell activity of peripheral blood lymphocytes as detected in a con-A/MLC assay, compared with that of 15 controls $(41.0 \pm 8.6 \%$ suppression compared with $59.4 \pm 5.2 \%$, mean $\pm \mathrm{SEM} ; 0.05<\mathrm{p}<0.1$ one-sided test). No differences were found in the percentages of $T \gamma$ cells (suppressor cells) and $T \mu$ cells (helper cells) between patients and controls. This is to our knowledge the first report of con-Ainduced suppressor cell activity and $T$ lymphocyte subpopulations in the peripheral blood of patients with ankylosing spondylitis.

Hypergammaglobulinaemia and the presence of autoantibodies are common immunological features of inflammatory rheumatic diseases. Patients with ankylosing spondylitis (AS, Bechterew's syndrome) also frequently have increased immunoglobulin levels, ${ }^{1-4}$ but they usually lack detectable autoantibodies, although increased frequency of IgG rheumatoid factor (IgG RF) and granulocytereactive antinuclear antibodies have been detected. ${ }^{2} 56$ In contrast to the humoral immunity, cellular immune responses in AS patients are usually normal, ${ }^{3}{ }^{7-10}$ even if reduced cellular responses to some antigens and to allogeneic cells have been observed. ${ }^{3} 911$

Disorders characterised by hypergammaglobulinaemia and the presence of autoantibodies, as well as hypogammaglobulinaemic conditions, may have a complex aetiology, but they can in part be explained by dysfunction in the suppressor and helper cell systems (the $T \gamma$ and $T \mu$ cell compartments). Imbalances in these cells might therefore result in hyper- or hyporesponsiveness of the immunocompetent lymphocytes (B and $T$ lymphocytes).

The present study was carried out to discover whether the immunological derangements in AS

Accepted for publication 20 February 1981.

Correspondence to Dr O. Vinje, Institute of Immunology and Rheumatology, Rikshospitalet University Hospital, F. Qvams gate 1, Oslo 1, Norway. patients (hypergammaglobulinaemia) were reflected in suppressor/helper cell dysfunction.

\section{Materials and methods}

Patients. Seventeen randomly chosen patients with AS diagnosed at Oslo Sanitetsforenings Rheumatism Hospital were examined. The 6 women and 11 men, all Norwegians, had an age distribution ranging from 20 to 48 years (mean 33 years). They were examined clinically as described elsewhere. ${ }^{12}$ The clinical data, biochemical values, and radiographic findings are listed in Table 1. Fifteen blood donors served as controls in the cellular tests.

Isolation of mononuclear cells. Peripheral blood mononuclear cells were isolated from heparinised blood by Isopaque-Ficoll gradient centrifugation. ${ }^{13}$ $T$ lymphocytes were enumerated and isolated by means of sheep red blood cells (SRBC) treated with 2-aminoethylisothiouronium bromide (AET, Sigma Chemical Co., St Louis, Mo). ${ }^{14}$

Detection of $T$ lymphocyte subpopulations $\left(T_{\gamma}\right.$ and $T \mu$ cells). For the detection of $T$ lymphocytes with receptors for the Fc part of IgG antibodies ( $\mathrm{T} \gamma$ cells), human $\mathbf{O}, \mathbf{R h}+$ erythrocytes sensitised with anti-Rh Ripley antibodies were used. ${ }^{15} 16 \mathrm{~T}$ lymphocytes with receptors for the Fc part of IgM antibodies ( $T \mu$ cells) were detected by their ability to form 
Table 1 Clinical, biochemical, and radiographic data of 17 patients with ankylosing spondylitis ${ }^{1}$

\begin{tabular}{|c|c|c|c|c|c|c|c|c|c|c|c|c|c|c|c|c|c|c|}
\hline \multicolumn{7}{|c|}{ Patients } & \multicolumn{8}{|c|}{ Biochemical values 5} & \multicolumn{4}{|c|}{ Radiographic findings } \\
\hline No. & Age & $\operatorname{Sex}$ & $\begin{array}{l}\text { Dur. } \\
(y r .)\end{array}$ & Psor. 2 & $A A U^{3}$ & Treat. 4 & $H b$ & $E S R$ & $W B C$ & $C R P$ & $C 3$ & $C 4$ & $B f$ & $\mathrm{CH}_{50}$ & $S I^{6}$ & Col. $^{7}$ & Large & Phal. 8 \\
\hline 1 & 26 & $\mathbf{M}$ & $2-5$ & - & + & 3 & $11 \cdot 7$ & 50 & $7 \cdot 300$ & 0.028 & 0.9 & 0.46 & 188 & 150 & 3 & + & - & - \\
\hline 2 & 48 & $\mathbf{M}$ & $>10$ & $?$ & + & 3 & $12 \cdot 4$ & 83 & 8.400 & 0.032 & 0.9 & 0.34 & 193 & 150 & 5 & + & + & + \\
\hline 3 & 47 & $\mathbf{M}$ & $>10$ & - & + & 2 & $14 \cdot 5$ & 37 & $7 \cdot 700$ & 0.012 & $1 \cdot 3$ & 0.65 & 140 & 150 & 3 & + & - & + \\
\hline 4 & 44 & $\mathbf{M}$ & $>10$ & - & + & 3 & $14 \cdot 6$ & 33 & $11 \cdot 800$ & 0.011 & 0.9 & 0.29 & 152 & 120 & 5 & + & + & - \\
\hline 6 & 35 & $\mathbf{F}$ & $>10$ & - & - & 2 & $13 \cdot 2$ & 35 & $9 \cdot 200$ & $<0.01$ & $1 \cdot 0$ & 0.59 & 139 & 130 & 3 & + & - & - \\
\hline 7 & 42 & $\mathbf{M}$ & $>10$ & + & - & 4,5 & 15.0 & 13 & $8 \cdot 700$ & 0.016 & 0.8 & 0.36 & 98 & 100 & 4 & + & + & + \\
\hline 8 & 34 & $\mathbf{M}$ & $>10$ & - & - & 3 & $15 \cdot 8$ & 22 & 8.600 & $<0.01$ & $1 \cdot 0$ & 0.48 & 152 & 160 & 3 & + & - & - \\
\hline 9 & 35 & F & $2-5$ & - & - & 2 & $15 \cdot 2$ & 14 & 8.900 & $>0.01$ & 0.7 & 0.36 & 108 & 160 & $2 \mathrm{~B}$ & - & - & - \\
\hline 10 & 24 & $\mathbf{M}$ & $5-10$ & - & + & 2 & $16 \cdot 2$ & 3 & 9.600 & $<0.01$ & 0.9 & 0.36 & 109 & 70 & 4 & + & - & - \\
\hline 11 & 26 & $\mathbf{F}$ & $5-10$ & + & - & 2 & $12 \cdot 4$ & 25 & 9.000 & $<0.01$ & 0.8 & 0.46 & 131 & 165 & 5 & + & + & - \\
\hline 12 & 23 & $\mathbf{M}$ & $2-5$ & - & - & 3,4 & $14 \cdot 0$ & 82 & $15 \cdot 000$ & 0.030 & $1 \cdot 3$ & $0 \cdot 37$ & 210 & 110 & $2 B$ & - & - & - \\
\hline 13 & 27 & $\mathbf{M}$ & $>10$ & - & + & 2 & $13 \cdot 8$ & 45 & $8 \cdot 500$ & 0.027 & 0.9 & 0.47 & 165 & 120 & 5 & + & + & - \\
\hline 14 & 20 & $\mathbf{M}$ & $5-10$ & - & - & 3 & 10.8 & 76 & 9.000 & 0.120 & $1 \cdot 3$ & 0.60 & 177 & 120 & 4 & - & + & - \\
\hline 16 & 25 & $F$ & $5-10$ & - & + & 4 & $11 \cdot 4$ & 15 & $8 \cdot 100$ & $<0.01$ & 0.6 & 0.21 & 58 & 120 & 4 & - & + & + \\
\hline 17 & 32 & $\mathbf{F}$ & $5-10$ & - & - & 3 & 13.4 & 10 & $\mathrm{Nd}^{9}$ & $<0.01$ & Nd & 0.36 & Nd & Nd & 4 & + & + & + \\
\hline
\end{tabular}

1 All patients were HLA B27 positive.

2Patients with dermatological findings typical of psoriasis.

3Patients giving a history of acute anterior uveitis (AAU).

4Treatment with anti-inflammatory drugs: $0=$ no treatment; $1=$ salicylates; $2=$ naproxene; $3=$ indomethacin; $4=$ prednisone.

${ }^{5}$ Normal values and $p$ values for the differences between patients and controls: white blood cell counts (WBC) 4 - $11 \times 10^{9}$ cells $/ 1$; C-reactive protein $(C R P)=<0.01 \mathrm{~g} / 1 ; \mathrm{p}<0.001 ; \mathrm{C} 3=0.73 \pm 0.01 \mathrm{~g} / 1, \mathrm{p}<0.001 ; \mathrm{C} 4=0.295 \pm 0.02 \mathrm{~g} / 1, \mathrm{p}<0.001 ;$ properdin factor $\mathrm{B}\left(\mathrm{B}_{\mathrm{f}}\right): 110 \pm 8 \%$, $\mathrm{p}<0.01 ; \mathrm{CH}_{50}=111 \pm 4.0 \%, \mathrm{p}>0.05$.

${ }^{6}$ Radiographic examination of sacroiliac (SI) joints, graded from 0 (normal joint) to 5 (bony ankylosis), according to Dahle ${ }^{39}$; Grade $2 B$ to 5 represents definite bilateral sacroiliitis.

${ }^{7}$ Radiographic inflammatory changes of the spine.

8The diagnosis of arthritis of large and phalangeal (Phal.) joints was also confirmed by clinical examination.

${ }^{9}$ Not determined.

rosettes with ox red blood cells (ORBC) sensitised with rabbit anti-ORBC IgM antibodies, according to methods described elsewhere. ${ }^{1517}$ One drop of $0.01 \%$ acridine orange was added to the cell suspensions before rosettes were counted at $250 \times$ magnification under UV and ordinary light simultaneously. For all rosettes, cells binding 3 or more erythrocytes were considered positive. At least 200 lymphocytes were scored in each cell suspension.

Suppressor cell assay. Peripheral blood mononuclear cells $\left(5 \times 10^{6}\right.$ cells $\left./ \mathrm{ml}\right)$ were incubated without or with concanavalin-A (con-A $20 \mu \mathrm{g} / \mathrm{ml}$ ) for $48 \mathrm{hr}$ at $37^{\circ} \mathrm{C}$ in an atmosphere of $5 \% \mathrm{CO}_{2} / 95 \%$ air and $100 \%$ humidity. ${ }^{18} 19$ After incubation both unstimulated and con-A-activated cells from the patients and the controls were irradiated (3000 R), washed twice with $30 \mathrm{mM} \alpha$-methyl D-mannoside in Hanks's balanced salt solution (HBSS) to remove con-A, then twice in RPMI (Roswell Park Memorial Institute) $1640+10 \%$ fetal calf serum (FCS) and antibiotics (complete medium), and resuspended in complete medium to a concentration of $1 \times 10^{6}$ viable cells $/ \mathrm{ml}$ (stimulator cells). Freshly isolated mononuclear cells (responder cells) from a normal donor were isolated as described above, and adjusted to a concentration of $1 \times 10^{6} \mathrm{cells} / \mathrm{ml}$ in complete medium.
One of us served as source of responder cells in all the experiments in order to ensure a reproducible con-Areactive responder cell population. In the 1-way mixed lymphocyte culture (MLC) experiments $0.1 \mathrm{ml}$ of stimulator cells were incubated with $0.1 \mathrm{ml}$ responder cells and con-A $(6 \mu \mathrm{g} / \mathrm{ml})$ in an atmosphere of $5 \% \mathrm{CO}_{2} / 95 \%$ air and $100 \%$ humidity for $144 \mathrm{hr}$ in microtitre plates (Costar 3596, Cambridge, Mass). $18 \mathrm{hr}$ prior to harvesting on a Skatron semiautomatic harvesting machine (Skatron, Lierbyen, Norway) the cells were labelled with $0.5 \mathrm{mCi}$ of ${ }^{3} \mathrm{H}$-thymidine (Amersham Radiochemicals, England). The incorporation of ${ }^{3} \mathrm{H}$-thymidine was measured by a liquid scintillation counter and the results expressed as mean cpm of triplicates \pm standard error of the mean. The percentage suppression was calculated according to the formula:

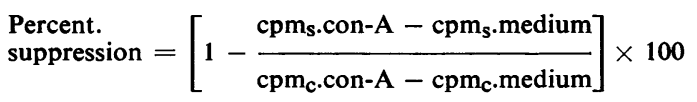

where $\mathrm{cpm}_{\mathrm{s}} . \mathrm{con}-\mathrm{A}$ is mean $\mathrm{cpm}$ in cultures containing suppressor cells and con-A; $\mathrm{cpm}_{\mathrm{s}}$. medium is mean cpm in cultures containing suppressor cells without con-A;cpm $\mathrm{cm}_{\mathrm{c}}$ con-A is mean $\mathrm{cpm}$ in control cultures with con-A; and $\mathrm{cpm}_{\mathbf{c}}$.medium is mean $\mathrm{cpm}$ in cultures containing control cultures but no con-A. 
$H L A$ typing. The patients were HLA typed with a standardised 2-stage lymphocytotoxicity micromethod.

Quantitations of immunoglobulins and complement factors and detection of autoantibodies. Serum was frozen at $-70^{\circ} \mathrm{C}$ and stored until all samples were collected. Quantitations of immunoglobulins, Creactive protein (CRP), and complement factors, and detection of autoantibodies were done as described in detail elsewhere. ${ }^{20} 21$ Total haemolytic complement activity $\left(\mathrm{CH}_{50}\right)$ was measured by a haemolytic assay in agarose plates ${ }^{22}$ and the results expressed as percentage of that found in a standard pool of blood donors. Fifty healthy adults served as controls in the different quantitations.

Statistical methods. Laboratory values are given as mean \pm standard error of the mean (SEM). Differences between groups were assessed by means of the Mann-Whitney U test. Significant probabilities equal to or less than 0.05 were considered significant. One-sided tests were used on 1-sided hypotheses.

\section{Results}

CLINICAL AND LABORATORY DATA

All patients fulfilled the criteria for ankylosing spondylitis ${ }^{23} 24$ and showed bilateral sacroliitis on radiographs. Thirteen patients also had radiographic changes of the spine. All patients were HLA B27 positive. The majority of the patients had active disease as judged from ESR, CRP, and com- plement factor levels. Detailed data are given in Table 1.

Serum IgA and IgM concentrations were increased $(3 \cdot 5 \pm 0 \cdot 5 \mathrm{~g} / 1$ and $1 \cdot 7 \pm 0 \cdot 2 \mathrm{~g} / 1$ in the patients versus $2 \cdot 3 \pm 0 \cdot 1 \mathrm{~g} / 1$ and $1 \cdot 4 \pm 0 \cdot 1 \mathrm{~g} / \mathrm{l}$ in the controls, $\mathrm{p}<0 \cdot 05,1$-sided test). Serum IgG concentration was also slightly elevated in the patient group, but the increase was not significant $(14 \cdot 3 \pm 1 \cdot 2 \mathrm{~g} / \mathrm{l}$ versus $12 \cdot 4 \pm 0 \cdot 4 \mathrm{~g} / \mathrm{l} ; 0.05<\mathrm{p}<0 \cdot 1,1$-sided test). Three patients had detectable autoantibodies. One patient (patient 2) had IgM RF in titre 128 (Waaler-Rose reaction); another (patient 5) had anti-smoothmuscle antibodies in titre 32 ; and the third (patient 4) had low titred antinuclear antibodies (ANA) (titre 8) and antiparietal antibodies (titre 16).

CON-A-INDUCED SUPPRESSOR CELL ACTIVITY AND T LYMPHOCYTE SUBPOPULATIONS

The peripheral blood lymphocytes from patients and controls (stimulator cells) were incubated with con-A for $48 \mathrm{hr}$ in order to generate maximal suppressor cell activity on to $T$ lymphocytes from a constant donor (responder cells). In this assay a suppression of $41 \cdot 0 \pm 8 \cdot 6 \%$ was detected in the patient group compared with $59 \cdot 4 \pm 5 \cdot 2 \%$ in the controls $(0 \cdot 05<\mathrm{p}<0 \cdot 1,1$-sided test $)$.

By means of different rosetting techniques the percentages of $\mathrm{T}$ lymphocytes (E-RFC), $\mathrm{T} \gamma$ cells (suppressor cells), and $\mathrm{T} \mu$ cells (helper cells) were determined. No abnormalities were detected (Table 2).

Four patients (nos. 5, 6, 8, and 17) had low suppressor cell activity $(\leqslant 20 \%$ ) (Table 3$)$. Their

Table 2 Con-A-induced suppressor-cell activity, $T$ lymphocyte subpopulations ( $T \gamma$ and Tu cells), and immunoglobulin concentrations in the peripheral blood of 17 patients with ankylosing spondylitis

\begin{tabular}{|c|c|c|c|c|c|c|}
\hline Pat. no. & $\%$ Suppr. & $T \gamma$ & $T \mu$ & $\operatorname{Ig} G(g / l)$ & $\operatorname{Ig} A(g / l)$ & $\operatorname{Ig} M(g / l)$ \\
\hline 1 & 59 & 26 & 54 & $12 \cdot 8$ & $4 \cdot 4$ & 0.9 \\
\hline 2 & 50 & 23 & 52 & $15 \cdot 9$ & $7 \cdot 4$ & $1 \cdot 8$ \\
\hline 3 & 29 & 9 & 44 & $14 \cdot 8$ & $4 \cdot 6$ & $2 \cdot 1$ \\
\hline 4 & 44 & 11 & - & $10 \cdot 0$ & $4 \cdot 2$ & $2 \cdot 5$ \\
\hline 5 & 11 & 8 & 50 & $16 \cdot 8$ & $6 \cdot 1$ & $1 \cdot 7$ \\
\hline 6 & -8 & 13 & 46 & $12 \cdot 8$ & $2 \cdot 5$ & $1 \cdot 1$ \\
\hline 7 & 88 & 8 & 77 & $9 \cdot 8$ & $3 \cdot 0$ & $1 \cdot 5$ \\
\hline 8 & 20 & 7 & 43 & $13 \cdot 6$ & $1 \cdot 2$ & $1 \cdot 2$ \\
\hline 9 & 77 & 6 & 53 & $7 \cdot 1$ & $1 \cdot 0$ & $2 \cdot 3$ \\
\hline 10 & 一 & 6 & - & $10 \cdot 9$ & $2 \cdot 4$ & $1 \cdot 7$ \\
\hline 11 & - & 11 & 一 & $11 \cdot 3$ & $4 \cdot 6$ & $1 \cdot 3$ \\
\hline 12 & 一 & 7 & 51 & $21 \cdot 4$ & $2 \cdot 7$ & $2 \cdot 2$ \\
\hline 13 & 67 & 13 & 55 & $15 \cdot 9$ & $4 \cdot 9$ & $3 \cdot 1$ \\
\hline 14 & - & 7 & 45 & $24 \cdot 8$ & $5 \cdot 3$ & $1 \cdot 2$ \\
\hline 15 & - & 7 & 54 & 17.9 & 0.8 & $3 \cdot 1$ \\
\hline 16 & 48 & 6 & 41 & $7 \cdot 5$ & 0.8 & 1.6 \\
\hline 17 & 7 & 22 & - & $19 \cdot 6$ & $2 \cdot 9$ & $0 \cdot 3$ \\
\hline \multicolumn{7}{|l|}{ Mean $\pm \mathbf{S E M}$} \\
\hline of patients & $41 \cdot 0 \pm 8 \cdot 6$ & $11 \cdot 1 \pm 1 \cdot 6$ & $51 \cdot 2 \pm 2 \cdot 5$ & $14 \cdot 3 \pm 1 \cdot 2$ & $3 \cdot 5 \pm 0 \cdot 5$ & $1 \cdot 7 \pm 0 \cdot 2$ \\
\hline of controls & $59 \cdot 4 \pm 5 \cdot 2$ & $13 \cdot 0 \pm 2 \cdot 0$ & $54 \cdot 7 \pm 2 \cdot 0$ & $12 \cdot 4 \pm 0.4$ & $2 \cdot 3 \pm 0 \cdot 1$ & $1 \cdot 4 \pm 0 \cdot 1$ \\
\hline
\end{tabular}

Three patients (nos. 2, 4, and 5) had autoantibodies in low titres). 
Table 3 Con-A-induced suppressor cell activity, $T \gamma$ and $T \mu$ cells, erythrocyte sedimentation rate (ESR), and immunoglobulin concentrations in different groups of patients with ankylosing spondylitis

\begin{tabular}{|c|c|c|c|c|c|c|c|}
\hline Pat. no. & $\%$ Suppr. & $\mathbf{T} \boldsymbol{\gamma}$ & $\mathbf{T} \mu$ & ESR & $\operatorname{IgG}(g / 1)$ & $\operatorname{IgA}(\mathrm{g} / \mathbf{1})$ & $\operatorname{IgM}(g / 1)$ \\
\hline \multicolumn{8}{|c|}{ Patients with low suppressor cell actvity } \\
\hline 5 & 11 & 8 & 50 & 60 & $16 \cdot 8$ & $6 \cdot 1$ & $1 \cdot 7$ \\
\hline 6 & -8 & 13 & 46 & 35 & $12 \cdot 8$ & $2 \cdot 5$ & $1 \cdot 1$ \\
\hline 8 & 20 & 7 & 43 & 22 & $13 \cdot 6$ & $1 \cdot 9$ & $1 \cdot 2$ \\
\hline 17 & 7 & 22 & 一 & 10 & $19 \cdot 6$ & $2 \cdot 9$ & $\mathbf{0} \cdot \overline{3}$ \\
\hline Mean \pm SEM & $7 \cdot 5 \pm 5 \cdot 8$ & $12 \cdot 5 \pm 3 \cdot 4$ & $46 \cdot 3 \pm 2 \cdot 0$ & $32 \pm 11$ & $15 \cdot 7 \pm 1 \cdot 6$ & $3 \cdot 4 \pm 0.9$ & $1 \cdot 1 \pm 0 \cdot 3$ \\
\hline 1 & 59 & 26 & 54 & 50 & $12 \cdot 8$ & $4 \cdot 4$ & 0.9 \\
\hline 7 & 88 & 8 & 77 & 13 & $9 \cdot 8$ & 3.0 & $1 \cdot 5$ \\
\hline 9 & 77 & 6 & 53 & 14 & $7 \cdot 1$ & $1 \cdot 0$ & $2 \cdot 3$ \\
\hline 13 & 67 & 13 & 55 & 45 & $15 \cdot 9$ & $4 \cdot 9$ & $3 \cdot 1$ \\
\hline Mean \pm SEM & $72 \cdot 8 \pm 6 \cdot 3$ & $13 \cdot 3 \pm 4 \cdot 5$ & $59 \cdot 8 \pm 5 \cdot 8$ & $31 \pm 10$ & $11 \cdot 4 \pm 1 \cdot 9$ & $3 \cdot 3 \pm 0 \cdot 9$ & $2 \cdot 0 \pm 0 \cdot 5$ \\
\hline \multicolumn{8}{|c|}{ Patients with high disease activity } \\
\hline 1 & 59 & 26 & 54 & 50 & $12 \cdot 8$ & $4 \cdot 4$ & 0.9 \\
\hline 2 & 50 & 23 & 52 & 83 & $15 \cdot 9$ & $7 \cdot 4$ & $1 \cdot 8$ \\
\hline 12 & - & 7 & 51 & 82 & $21 \cdot 4$ & $2 \cdot 7$ & $2 \cdot 2$ \\
\hline Mean \pm SEM & $40 \cdot 0 \pm 14 \cdot 7$ & $16 \cdot 0 \pm 4 \cdot 9$ & $51 \cdot 8 \pm 0.9$ & $69 \pm 8$ & $16 \cdot 7 \pm 1 \cdot 8$ & $5 \cdot 2 \pm 1 \cdot 0$ & $1 \cdot 7 \pm 0 \cdot 3$ \\
\hline \multicolumn{8}{|c|}{ Patients with high total immunoglobulin concentration } \\
\hline 2 & 50 & 23 & 52 & 83 & $15 \cdot 9$ & $7 \cdot 4$ & $1 \cdot 8$ \\
\hline 5 & 11 & 8 & 50 & 60 & $16 \cdot 8$ & $6 \cdot 1$ & $1 \cdot 7$ \\
\hline 13 & 67 & 13 & 55 & 45 & $15 \cdot 9$ & $4 \cdot 9$ & $3 \cdot 1$ \\
\hline Mean \pm SEM & $42 \cdot 7 \pm 16 \cdot 6$ & $14 \cdot 7 \pm 4 \cdot 4$ & $52 \cdot 3 \pm 1 \cdot 5$ & $63 \pm 11$ & $16 \cdot 2 \pm 0 \cdot 3$ & $6 \cdot 1 \pm 0 \cdot 7$ & $2 \cdot 2 \pm 0 \cdot 5$ \\
\hline \multicolumn{8}{|c|}{ Patients with low total immunoglobulin concentration } \\
\hline 7 & 88 & 8 & 77 & 13 & $9 \cdot 8$ & $3 \cdot 0$ & $1 \cdot 5$ \\
\hline 9 & 77 & 6 & 53 & 14 & $7 \cdot 1$ & $1 \cdot 0$ & $2 \cdot 3$ \\
\hline 16 & 48 & 6 & 41 & 15 & $7 \cdot 5$ & 0.8 & $1 \cdot 6$ \\
\hline Mean \pm SEM & $71 \cdot 0 \pm 11 \cdot 9$ & $6 \cdot 7 \pm 0 \cdot 7$ & $57.0 \pm 10 \cdot 6$ & $14 \cdot 0 \pm 0.6$ & $8 \cdot 1 \pm 0.8$ & $1 \cdot 6 \pm 0.7$ & $1 \cdot 8 \pm 0 \cdot 3$ \\
\hline
\end{tabular}

percentages of $T \gamma$ and $T \mu$ cells did not differ from those in the rest of the patients or the controls. No deviations were found in IgG and IgA concentrations between these 4 patients and the rest of the patient group, but the IgM concentration was reduced $(1 \cdot 1 \pm 0 \cdot 3 \mathrm{~g} / 1$ versus $1 \cdot 9 \pm 0 \cdot 2 \mathrm{~g} / 1 ; \mathrm{p}<0 \cdot 05)$. Low suppressor cell activity was found both in patients with high and those with low disease activity as judged from ESR and CRP (Tables 1 and 3).

Four patients (nos. 1, 7, 9, 13) with high suppressor cell activity $(\geqslant 59 \%)$ had normal proportions of $T$ lymphocyte subpopulations. The mean IgG concentration was slightly lower and the IgM concentration slightly higher than in the rest of the patients, but these variations did not reach statistical significance.

No differences in suppressor cell activity, or in the percentages of $T \gamma$ and $T \mu$ cells were found between the 3 patients with high total immunoglobulin concentrations $(>23 \mathrm{~g} / \mathrm{l})$ and the other patients (Table 3).

Three patients with low total immunoglobulin levels $(<15 \mathrm{~g} / \mathrm{l})$ showed a moderately increased suppressor cell activity compared with the remaining patients $(71 \pm 11.9 \%$ versus $31 \pm 8 \cdot 5 \%, 0.05<\mathrm{p}<$
$0 \cdot 1)$. The percentage of $\mathrm{T} \gamma$ cells in these patient : was lower $(6 \cdot 7 \pm 0 \cdot 7 \%$ versus $12 \cdot 1 \pm 1 \cdot 9 \%$, $\mathrm{p}<0.05$ ), while $\mathrm{T} \mu$ cell percentages showed no significant deviation (Table 3 ).

No differences in suppressor cell activity or in $\mathbf{T}$ lymphocyte subpopulations were seen between patients with or without peripheral joint or spine involvement, or a history of acute anterior uveitis. One patient (no. 7) had severe psoriatic arthropathy. $\mathrm{He}$ also had the highest suppressor cell activity and the highest percentage of $\mathrm{T} \mu$ cells in the total patient group (Table 1).

\section{Discussion}

A reduction in con-A-induced suppressor cell activity was detected in the peripheral blood of some patients with AS. T lymphocyte subpopulations with so-called suppressor and helper cell markers ( $\mathrm{T} \gamma$ and $T \mu$ cells) were within the normal range. These observations may correspond with the moderately elevated humoral responses now detected, and with the normal cellular responses currently found in these patients. ${ }^{3}$ 7-10 $\mathrm{We}$ have measured suppressor cell activity in a $\mathrm{T}$ cell system (con-A MLC), and, since it is not known whether the same or different 
cells regulate $B$ and $T$ cell activities, the possibility that polyclonal $\mathrm{B}$ cell activators are responsible for the elevated immunoglobulin concentrations in some AS patients must also be considered. One possible B cell activator in AS patients is Klebsiella pneumoniae, a micro-organism which may cause chronic infections in AS patients because of similarities between bacterial and host antigens (HLA B27). ${ }^{25}$ Owing to this antigenic similarity the micro-organism might be recognised as 'self' and thus escape normal defence mechanisms of the host's immune system.

Studies of patient subgroups characterised by significantly reduced or increased suppressor cell activity, or by reduced or elevated percentages of cells with suppressor and helper cell markers, respectively, revealed no clear association between markers and functions. This lack of association may be due to the heterogeneity of the T $\gamma$ cell population, which comprise cells active in antibody-dependent cell-mediated cytotoxicity, ${ }^{26}{ }^{27}$ as natural killer cells $^{27}$ as well as suppressor cells. ${ }^{28}$ Functional heterogeneity may also be found in the $T \mu$ cell compartment. AS patients with the lowest total immunoglobulin levels had the most increased suppressor cell activity, indicating that detectable suppressor and helper cell disturbances may be found in AS patients with deviating activity in the immune system. However, no direct association was observed between suppressor cell activity, cells with suppressor and helper cell markers, and clinical parameters.

One of the patients (no. 5) was not on drug treatment. This patient had clinically a high disease activity, high levels of immunoglobulins, low suppressor cell activity, and a reduced percentage of cells with suppressor cell markers. The rest of the patients received various drugs (prednisone, naproxene, indomethacin, salicylates), and, as it is known that certain anti-inflammatory drugs-for example, prednisone, cyclophosphamide-have the capacity to normalise con-A-induced suppressor cell activity, ${ }^{29-31}$ the possibility exists that suppressor cell dysfunctions may be partly corrected in the treated patients.

This is to our knowledge the first report on suppressor cell activity and $\mathrm{T}$ cell subpopulations in patients with AS. Investigations of suppressor and helper cells in other rheumatic diseases, such as systemic lupus erythematosus (SLE), juvenile rheumatoid arthritis (JRA), and rheumatoid arthritis (RA), have shown a spectrum of results from a highly significant reduction of suppressor cell activity and cells with suppressor cell markers in patients with SLE, ${ }^{32} 33$ through normal suppressor cell activity but reduced percentages of cells with suppressor cell markers in patients with JRA, ${ }^{3435}$ to only minor deviations in RA patients ${ }^{34}$ and now also in AS patients. These different findings clearly demonstrate the complexity of immunoregulation, and they also suggest that different mechanisms may operate in the different rheumatic diseases. Furthermore, the results from RA patients with a local suppressor cell defect in synovial tissue lymphocytes ${ }^{36} 37$ combined with normal suppressor cell activity in the peripheral blood lymphocytes ${ }^{\mathbf{3 4}}$ show that, in spite of normal findings in the peripheral blood, local derangements in immunoregulatory cells may be detected in the diseased joints. This may also be true of patients with AS.

The familial occurrence of ankylosing spondylitis is well known The HLA B27 antigen, which is autosomally codominantly inherited, is present in most affected patients. But why some but not all persons born with this genetic marker contract the disease is not known. Certain infections (caused by, for example, salmonella strains and shigella strains) may induce arthritis in HLA B27 positive persons, indicating that AS may be a reactive disorder. One report also claims that decreased suppressor cell activity can be genetically determined. ${ }^{38}$ Our study revealed only minor aberrations in the suppressor cell function in AS patients. Family studies are needed to clarify whether the suppressor cell dysfunction observed in some AS patients segregates as a genetic marker in their families.

The present study demonstrated almost normal suppressor cell activity in AS patients in an unspecific mitogen-induced suppressor cell assay (the con-A MLC assay). However, suppressor and helper cell systems measuring specific immune responses against possible aetiological antigens-for example, strains of Klebsiella pneumoniae, salmonella, and shigella-may be more useful for the detection of immunological defects in patients with AS.

This work was supported by the Norsk Hydro Company. The authors thank Jorun Grandaunet, Tove Skodje, and Elisiv Rogge Wang for technical assistance. The secretarial assistance of Sissel Bergersen is gratefully acknowledged.

\section{References}

1 Eghtedari A A, Davis P, Bacon P A. Immunological reactivity in ankylosing spondylitis. Circulating immunoblasts, autoantibodies, and immunoglobulins. Ann Rheum Dis 1976; 35: 155-7.

2 Howell F A, Chamberlain M A, Perry R A, Torrigiani G, Roitt I M. IgG antiglobulin levels in patients with psoriatic arthropathy, ankylosing spondylitis and gout. Ann Rheum Dis 1972; 31: 129-31.

3 Nikbin B, Brewerton D A, Byrom N, et al. Lymphocyte function in ankylosing spondylitis. Ann Rheum Dis 1975; 34 (suppl I): 49-52.

4 Veys E M, van Laere M. Serum IgG, IgM, and IgA levels in ankylosing spondylitis. Ann Rheum Dis 1973; 32: 493-6. 
5 Arana R M, de la Vega M I, Porrini A, Morteo O Garcia. Anti-globulins in ankylosing spondylitis. $J$ Rheumatol $1975 ; 2$ : 303-7.

${ }^{6}$ Vasey F B, Kinsella T D. Increased frequency of leukocyte-reactive antinuclear antibody in patients with ankylosing spondylitis. J Rheumatol 1977; 4: 158-64.

7 Bluestone R, Goldberg L S, Weisbart R H, Morris R I, Holborow E J. Aberrant immunity in (HL-A) W27positive rheumatic disease. Ann Rheum Dis 1975; 34 (suppl I) : 46-8.

8 Fan P T, Clements P J, Yu D T Y, Opelz G, Bluestone R. Lymphocyte abnormalities in ankylosing spondylitis. Ann Rheum Dis 1977; 36: 471-3.

${ }^{9}$ Seager K, Bashir H V, Geczy A F, Edmonds J, de VereTyndall A. Evidence for a specific B27-associated cell surface marker on lymphocytes of patients with ankylosing spondylitis. Nature 1977; 277 : 68-70.

10 Zilko P J, Thevathasan M, Dawkins R L. Immune function in ankylosing spondylitis: apparent relationship between streptococcal responses and HLA B27. J Rheumatol 1977; 4 (suppl 3): 49-53.

11 Nikbin B, Brewerton D A, James D C O, Hobbs J R. Diminished mixed lymphocyte reaction in ankylosing spondylitis, relatives, and normal individuals all with HL-A27. Ann Rheum Dis 1976; 35: 37-9.

12 Møller P, Vinje O. Arthropathy and sacroliitis in severe psoriasis. Scand J Rheumatol 1980; 9: 113-7.

13 Bøyum A. Isolation of lymphocytes, granulocytes and macrophages. Scand J Immunol 1976; 5 (suppl 5): 9-15.

14 Pellegrino M A, Ferrone S, Dierich M P, Reisfeld R A. Enhancement of sheep red blood cell human lymphocyte rosette formation by the sulfhydryl compound 2-amino ethylisothiouronium bromide. Clin Immunol Immunopathol 1975; 3: 324-33.

15 Dobloug J H, Førre Ø, Lea T, Solheim B G, Natvig J B. Detection of Fc-receptor-bearing human lymphocytes. The majority of T $\mu$ cells carry HLA-DR antigens. Clin Immunol Immunopathol in press.

16 Frøland S S, Natvig J B. Identification of three different human lymphocyte populations by surface markers. Transplant Rev 1973; 16: 114-62.

17 Moretta L, Ferrarini M, Durante M L, Mingari M C. Expression of a receptor for IgM by human T cells in vitro. Eur J Immunol 1975; 5: 565-9.

18 Hubert C, Delespesse G, Govaerts A. Concanavalin Aactivated suppressor cells in normal human peripheral blood lymphocytes. Clin Exp Immunol 1976; 26: 95-8.

19 Shou L, Schwartz S A, Good R A. Suppressor cell activity after concanavalin A treatment of lymphocytes from normal donors. J Exp Med 1976; 143: 1100-10.

20 Mancini G, Carbonara A O, Heremans J F. Immunochemical quantitation of antigens by single radial immunodiffusion. Immunochemistry 1965; 2: 235-54.

21 Vinje O, Møller P, Mellbye O J. Laboratory findings in patients with psoriasis, with special reference to immunological parameters, associations with arthropathy and sacro-iliitis. Scand J Rheumatol 1980; 9: 97-105.

22 Lachmann P J, Hobart M J. Complement technology. In: Weir D M, ed. Handbook of Experimental Immunology. 3rd ed. Oxford: Blackwell Scientific Publications, 1978: 5A.

${ }^{23}$ Bennet $\mathrm{P}$ H J, Burch T A. New York symposium on population studies in the rheumatic diseases: new diagnostic criteria. Bull Rheum Dis 1967; 17: 453.

${ }^{24}$ Kellgren J H, Jeffrey M R, Ball J. Epidemiology of Chronic Rheumatism. Oxford: Blackwell, 1963: 326-7.

${ }_{25}$ Seager K. Bashir H V, Geczy A F, Edmonds J, de Vere-Tyndall A. Evidence for a specific B27-associated cell surface marker on lymphocytes of patients with ankylosing spondylitis. Nature 1979; 277: 68-70.

26 Dobloug J H, Thorsteinsson L, Førre Ø, Mellbye O J, Natvig J B. Erythrocytes coated with anti-Rh Ripley react with both the $T$ and the non-T lymphocytes active in antibody-dependent cell-mediated cytotoxicity. Clin Immunol Immunopathol 1980; 17: 102-9.

27 Kay H D, Bonnard G D, West W H, Herberman R B. A functional comparison of human Fc-receptor-bearing lymphocytes active in natural cytotoxicity and antibodydependent cellular cytotoxicity. J Immunol 1977; 118: 2058-66.

28 Moretta L, Webb S R, Grossi C E, Lydyard P M, Cooper M D. Functional analysis of two human T-cell subpopulations: help and suppression of B-cell responses by $\mathrm{T}$ cells bearing receptors for IgM or IgG. J Exp Med 1977; 146: 184-200.

29 Braciale V L, Parish C R. Inhibition of in vitro antibody synthesis by cyclophosphamide-induced suppressor cells. Cell Inminol 1980: 51: 1-12.

30 Haynes B F, Katz P, Fauci A S. Mechanisms of corticosteroid action on lymphocyte subpopulations. Cell Immunol 1979; 44: 169-78.

31 Knapp W, Posch B. Concanavalin A-induced suppressor cell activity: opposing effects of hydrocortisone. $J$ Immunol 1980; 124: 168-72.

32 Bresnihan B, Jasin H E. Suppressor function of peripheral blood mononuclear cells in normal individuals and in patients with systemic lupus erythematosus. $J$ Clin Invest 1977; 59: 106-16.

${ }^{33}$ Hamilton $\mathbf{M}$ E, Winfield $\mathbf{J}$ B. T $\gamma$ cells in systemic lupus erythematosus. Variation with disease activity. Arthritis Rheum 1979; 22: 1-6.

34 Dobloug J H, Førre Ø, Chattopadhyay C, Høyeraal H M, Natvig J B. Con-A-induced suppressor cell activity and T-lymphocyte subpopulations in the peripheral blood of patients with rheumatoid arthritis and juvenile rheumatoid arthritis. Scand J Immunol in press.

35 Strelkauskas A J, Callery R T, McDowell J, Borel Y, Schlossman S F. Direct evidence for loss of human suppressor cells during active autoimmune disease. Proc Natl Acad Sci USA 1978; 75: 5150-4.

${ }^{36}$ Chattopadhyay C, Chattopadhyay H, Natvig J B, Michaelsen. T E, Mellbye O J. Lack of suppressor cell activity in rheumatoid synovial lymphocytes. Scand $J$ Immunol 1979; 10: 309-16.

37 Chattopadhyay C, Chattopadhyay H, Natvig J B, Mellbye O J. Rheumatoid synovial lymphocytes lack concanavalin-A-activated suppressor cell activity. Scand J Immunol 1979; 10: 479-86

38 Miller K B, Schwartz R S. Familial abnormalities of suppressor cell function in systemic lupus erythematosus. N Engl J Med 1979; 301: 803-9.

39 Dahle K. Radiographic grading of sacroiliitis in Bechterew's syndrome and allied disorders. Scand $J$ Rheumatol in press. 